\title{
PENGARUH PEMBERIAN SUPLEMEN ZINK TERHADAP STATUS GIZI ANAK SEKOLAH DASAR
}

\author{
Faris Muhammad ${ }^{1}$, Siti Nurhajjah ${ }^{2}$, Gusti Revilla ${ }^{2}$
}

\begin{abstract}
Abstrak
Penanganan gizi buruk selalu dikaitkan dengan makronutrisi padahal mikronutrisi juga penting. Zink merupakan mikronutrisi yang penting untuk sintesis protein, diferensiasi sel dan pertumbuhan. Kurangnya asupan zink dapat menganggu pertumbuhan. Tujuan penelitian ini adalah menentukan pengaruh pemberian suplemen zink terhadap status gizi anak sekolah dasar. Studi ini adalah true experimental dengan rancangan pre test-post test grup design yang dilakukan selama 3 bulan. Subjek penelitian sebanyak 33 orang dengan usia $7-9$ tahun yang memenuhi kriteria inklusi dan ekslusi. Subjek dibagi menjadi 2 kelompok yaitu kelompok 1 (teratur) 14 orang dan kelompok 2 (tidak teratur) 19 orang. Hasil uji t berpasangan terhadap pengukuran rerata Berat Badan (BB), Tinggi Badan (TB) dan Indek Massa Tubuh (IMT). Pre test dan post test untuk kelompok 1 dan kelompok 2 didapatkan nilai $p=0,000, p=0,000$, $p=0,000, p=0,000$, dan $p=0,051, p=0,682$. Hasil uji Anova one way terhadap pengukuran BB, TB dan IMT post test diantara kedua kelompok didapatkan nilai $p=0,053, p=0,117$ dan $p=0,211$. Simpulan studi ini adalah terdapat perbedaan yang bermakna BB dan TB pre-test dan post-test kedua kelompok namun IMT menunjukan hasil tidak bermakna pada pre-test dan post-test kedua kelompok. Tidak terdapat perbedaan yang bermakna BB,TB, dan IMT antara kelompok 1 dan kelompok 2.
\end{abstract}

Kata kunci: zink, berat badan, tinggi badan, indek massa tubuh

\begin{abstract}
Handling the malnutrition has always associated with macronutrients when micronutrients are also important. Zinc is an important micronutrient for protein synthesis, cell differentiation and growth. The lack of zinc intakes can disrupt growth. The objective of this study was to determine the effect of zinc supplementation on nutrional status of primary school student.This research was true experimental with pre and post test group design. This research was conducted for 3 months. The subjects of this study were 33 students with range of age 7-9 years old who met the criteria of inclusion and exclusion. Subjects were divided into 2 groups: group 1 (routine) with 14 students and group 2 (not routine) with 19 students. The result of paired t-test to analyze weight, height and body mass index means pre and post test for group 1 and group 2 were $p=0.000, p=0.000, p=0.000, p=0.000$ and $p=0.051, p=0.682$. One Way Anova test results on the measurement of weight, height and BMI post test between the two groups were obtained $p=0.053$, $p=0.117$ and $p=0.211$. Based on the results of the study, there were significant differences in weight and height pre and post test of both groups but BMI pre and post test of both groupsshowed no significant results. The conclusion is there were no significant differences between weight, height, and BMI between group 1 and group 2.
\end{abstract}

Keywords: zinc, height, weight, body mass index

Affiliasi penulis: 1. Prodi Kedokteran Fakultas Kedokteran Universitas Andalas Padang (FK Unand), 2. Bagian Anatomi FK Unand

Korespondensi: Faris Muhammad, Email: farisfaurizal@gmail.com,Telp: 081325714668

\section{PENDAHULUAN}

Permasalahan gizi buruk di Indonesia masih menjadi pekerjaan bersama yang belum sepenuhnya terselesaikan. Hal ini terbukti dari perbaikan status gizi 
menjadi salah satu dari delapan tujuan yang akan dicapai dalam Millenium Development Goals (MDGs) 2015yang diadopsi dari PBB tahun 2000. ${ }^{1}$ Perbaikan status gizi juga menjadi salah satu sasaran pokok Rencana Strategis Kementrian Kesehatan Tahun 2015-2019. Salah satu tujuan akhir dari perbaikan gizi ini adalah meningkatkan status gizi dan Sumber Daya Manusia (SDM). ${ }^{2}$

Perbaikan status gizi perlu perhatian khusus terutama pada anak usia sekolah sehingga dapat menjadi SDM yang berkualitas. Generasi yang berkualitas dapat diwujudkan dengan perhatian sedini mungkin baik dari segi jasmani, rohani, maupun ilmu pengetahuan. Program perbaikan status sudah ada di Puskesmas terutama pada ibu hamil, bayi dan balita, sementara pada anak Sekolah Dasar (SD), remaja, dewasa dan lanjut usia belum banyak dilakukan. Perbaikan gizi anak SD merupakan salah satu langkah strategis karena dampaknya secara langsung berkaitan dengan SDM yang berkualitas. ${ }^{3,4}$

Persoalan gizi dalam masyarakat merupakan faktor multidimensi yang menjadi penyebab munculnya kasus gizi buruk dan gizi kurang. Salah satu bagian yang sangat penting adalah kecukupan pangan. Asupan gizi yang kurang menyebabkan anak menjadi kurus dan pendek yang merupakan salah indikator dari status gizi pada anak. ${ }^{5,6}$

Prevalensi kurus secara global anak usia 5-19 tahun pada tahun 2013 berkisar 10,7\%, sedangkan pada tahun 2015 prevalensi pendek secara global berkisar 22,9\%. ${ }^{7}$ Data Riskesdas 2013 menunjukkan bahwa secara nasional prevalensi pendek dan kurus di Indononesia masih berada diatas angka global. Hal ini tercatat pada anak usia 5-12 tahun prevalensi pendek adalah $30,7 \%$ (12,3\% sangat pendek dan $18,4 \%$ pendek) dan prevalensi kurus (menurut indeks massa tubuh/usia) adalah $11,2 \%$ ( terdiri dari $4,0 \%$ sangat kurus dan $7,2 \%$ kurus). ${ }^{8}$ Beberapa provinsi di Indonesia menunjukan prevalensi kurus dan pendek diatas nilai nasional, salah satunya Sumatera Barat. Kabupaten Padang Pariaman menunjukan prevalensi pendek dan kurus pada angka 33,5\% dan 9,2\%. ${ }^{9}$

Status gizi berdasarkan antropometri lebih dikaitkan dengan asupan zat gizi makro (karbohidrat, protein dan lemak). Padahal peranan zat gizi makro tidak akan optimal tanpa kehadiran zat gizi mikro (vitamin dan mineral spesifik). Mineral yang termasuk zat gizi mikro antara lain adalah besi, zink, tembaga, selenium, chromium, iodium, fluorine, mangan, molybdenium, nikel, silikon, vanadium, arsenik dan cobalt. Kurangnya asupan mineral spesifik ini, salah satunya zink dapat menganggu pertumbuhan..$^{10,11}$

Zink merupakan mikronutrisi yang penting untuk sintesa protein, diferensiasi sel dan pertumbuhan. ${ }^{12}$ Zink juga merupakan agen anti inflamasi dan antioksidan pada tubuh manusia. ${ }^{13}$ Zink merupakan zat mikronutrisi yang dibutuhkan dalam jumlah sedikit akan tetapi mutlak harus ada di dalam tubuh, karena zink tidak bisa digantikan oleh zat gizi lain. Kecukupan zink ini sangat berguna untuk individu terutama pada anak yang mana pada anak tersebut terjadi pertumbuhan dan perkembangan. ${ }^{14,15}$

Penelitian tentang pengaruh zink terhadap pertumbuhan pertama kali dilakukan oleh Prasad (2013). Pemberian suplemen zink pada penelitian tersebut memperlihatkan terjadi peningkatan tinggi badan pada anak 12,7-15,2 cm dalam 1 tahun. ${ }^{12}$ Penelitian lain menunjukan terjadi perbaikan pertumbuhan dan perkembangan pada anak dwarfism, hypogonadism, hypogammaglobulinemia, giardiasis, strongyloidosis, schistosomiasis. ${ }^{16}$ Penelitian tentang pengaruh zink di Indonesia yang dilakukan menunjukan pada kelompok pemberian zink saja untuk nilai Z-skor menurun sampai batas yang lebih tinggi daripada plasebo. ${ }^{17}$

Peran zink dalam pertumbuhan erat kaitannya dengan peningkatan konsentrasi plasma Insulin-like Growth Factor I (IGF I). Insulin-like Growth Factor I merupakan mediator hormon pertumbuhan yang berperan sebagai suatu growth promoting factor dalam proses pertumbuhan. Penurunan konsentrasi IGF-I disebabkan bukan hanya karena kekurangan energi protein tetapi juga defisiensi zink. ${ }^{18}$

Prevalensi defisiensi zink pada penduduk dunia tahun 2016 sebesar $17 \% .{ }^{19}$ Defesiensi zink di Indonesia merupakan masalah gizi mikro yang belum sepenuhnya teratasi, hal ini ditunjukkan dengan angka kejadian defisiensi zink yang masih tinggi . Balita di Indonesia mengalami defisiensi zink sebesar 32\% pada tahun 2006. ${ }^{11}$ 
Manifestasi klinis lain yang dapat muncul pada kekurangan asupan zink adalah penurunan nafsu makan, kemampuan penyembuhan luka yang buruk, gangguan kulit, alopesia, gangguan neuropsikiatri dan penurunan sistem imunitas tubuh. Bahkan, jika tidak dapat dikenali dan ditatalaksana pada anak bisa menyebabkan kegagalan pematangan organ reproduksi hingga kematian. Kekurangan zink ini erat kaitannya dengan asupan yang kurang dan gangguan penyerapan. ${ }^{12,13,20}$

\section{METODE}

Jenis penelitian ini adalah studi true experimental dengan rancangan penelitian pre testpost test control grup design. Penelitian ini dilakukan setelah mendapat kelayakan etik (ethical clearance) dari Komisi Etik Penelitian Fakultas Kedokteran Universitas Andalas.

Populasi penelitian adalah seluruh siswa SDN 13 Batang Anai kelas 2 - 3 yang hadir saat acara pengabdian masyarakat. Sampel penelitian merupakan populasi yang memenuhi kriteria inklusi dan eksklusi. Teknik pengambilan sampel pada penelitian ini adalah total sampling dimana setiap populasi yang hadir dijadikan sebagai sampel penelitian.

Penelitian ini dilakukan selama 3 bulan. Subjek penelitian ini sebanyak 33 orang dengan usia 7 sampai 9 tahun yang memenuhi kriteria inklusi dan ekslusi. Data awal diambil saat pre test (sebelum diberikan zink) kemudian diberikan suplemen zink selama 3 bulan dan data selanjutnya diambil saat post test (setelah diberikan zink). Pada saat akhir subjek dibagi menjadi 2 kelompok yaitu kelompok 1 (teratur mengkonsumsi suplemen zink) 14 orang dan kelompok 2 (tidak teratur mengkonsumsi suplemen zink) 19 orang. Subjek dibagi berdasarkan kartu kontrol konsumsi zink yang diberikan kepada orang tua subjek.

\section{HASIL}

Hasil uji normalitas yang dilakukan pada data menggunakan Saphiro wilk menunjukan data berdistribusi normal, selanjutnya tes homogenitas yang dilakukan pada data penelitian ini menunjukan bahwa data bersifat homogen dengan signifikansi $>0,05$.

Pada Tabel 1menunjukan rerata BB kelompok yang mengkonsumsi suplemen zink secara teratur pada saat pre test adalah 22,89 $\pm 3,10 \mathrm{~kg}$ dan pada kelompok yang mengkonsumsi secara tidak teratur adalah $20,74 \pm 3,23 \mathrm{~kg}$. Pengukuran selanjutnya didapatkan rerata BB kelompok yang mengkonsumsi suplemen zink secara teratur pada saat post test meningkat menjadi $24,47 \pm 3,65 \mathrm{~kg}$ dan pada kelompok yang mengkonsumsi secara tidak teratur adalah $21,48 \pm 3,46 \mathrm{~kg}$. Uji $t$ berpasangan didapatkan nilai p pada BB kelompok teratur 0,000 dan BB kelompok tidak terartur 0,000. Uji Anova one way pada BB postest didapatkan nilai $p=0,053$.

Tabel 1. Distribusi pengukuran erata berat badan subjek penelitian pre test dan post test pada masingmasing kelompok anak

\begin{tabular}{lllllr}
\hline \multirow{2}{*}{ Pengukuran } & \multicolumn{2}{l}{ Teratur } & \multicolumn{3}{l}{ Tidak Teratur } \\
\cline { 2 - 6 } Berat Badan & Pre & Post & Pre & Post \\
& Test & Test & Test & \multicolumn{1}{c}{ Test } \\
& $\mathbf{( k g )}$ & $\mathbf{( k g )}$ & $\mathbf{( k g )}$ & $\mathbf{( k g )}$ \\
\hline Rerata & 22,89 & 24,47 & 20,74 & 21,48 \\
SD & 3,10 & 3,65 & 3,23 & 3,46 \\
Minimum & 19,90 & 20,10 & 16,10 & 16,80 \\
Maximum & 30,00 & 33,70 & 28,60 & 29,80 \\
Nilai p & \multicolumn{2}{c}{0,000} & \multicolumn{2}{c}{0,000} \\
\hline
\end{tabular}

Pada Tabel 2 terlihat rerata TB kelompok yang mengkonsumsi suplemen zink secara teratur pada saat pre test adalah $123,20 \pm 6,90 \mathrm{~cm}$ dan pada kelompok yang mengkonsumsi secara tidak teratur adalah $119,88 \pm 6,62 \mathrm{~cm}$. Pengukuran selanjutnya didapatkan rerata TB kelompok yang mengkonsumsi suplemen zink secara teratur pada saat post test meningkat menjadi $125,70 \pm 7,08 \mathrm{~kg}$ dan pada kelompok yang mengkonsumsi secara tidak teratur adalah $121,86 \pm 6,52 \mathrm{~kg}$. Uji $t$ berpasangan didapatkan nilai p pada TB kelompok teratur 0,000 dan TB kelompok tidak terartur 0,000. Uji Anova one way pada TB postest didapatkan nilai $\mathrm{p}=0,117$. 
Tabel 2. Distribusi pengukuran rerata tinggi badan subjek penelitian pre test dan post test pada masingmasing kelompok anak

\begin{tabular}{llllr}
\hline & \multicolumn{2}{l}{ Teratur } & \multicolumn{3}{l}{ Tidak Teratur } \\
\cline { 2 - 6 } Pengukuran & Pre & Post & Pre & \multicolumn{1}{c}{ Post } \\
Berat Badan & Test & Test & Test & \multicolumn{1}{c}{ Test } \\
& $\mathbf{( k g )}$ & $\mathbf{( k g )}$ & $\mathbf{( k g )}$ & $\mathbf{( k g )}$ \\
\hline Rerata & 123,20 & 125,70 & 119,88 & 121,86 \\
SD & 6,90 & 7,08 & 6,62 & 6,52 \\
Minimum & 115,10 & 118,30 & 110,10 & 113,20 \\
Maximum & 141,50 & 145,30 & 138,00 & 139,00 \\
Nilai p & \multicolumn{2}{c}{0,000} & \multicolumn{2}{c}{0,000} \\
\hline
\end{tabular}

Tabel 3 menunjukan rerata IMT kelompok yang mengkonsumsi suplemen zink secara teratur pada saat pre test adalah $14,80 \pm 1,63$ dan pada kelompok yang mengkonsumsi secara tidak teratur adalah 14,56 $\pm 1,26$. Pengukuran selanjutnya didapatkan rerata IMT kelompok yang mengkonsumsi suplemen zink secara teratur pada saat post test meningkat menjadi 15,16 \pm 1,74 dan pada kelompok yang mengkonsumsi secara tidak teratur turun menjadi 14,52 $\pm 1,14$. Hasil uji $t$ berpasangan didapatkan nilai $\mathrm{p}$ IMT kelompok teratur 0,051 dan IMT kelompok tidak terartur 0,682. Uji Anova one way pada BB postest didapatkan nilai $\mathrm{p}=0,053$.

Tabel 3. Distribusi penghitungan rerata indeks massa tubuh subjek penelitian pre test dan post test pada masing-masing kelompok anak

\begin{tabular}{lllllr}
\hline \multirow{2}{*}{ Pengukuran } & \multicolumn{2}{l}{ Teratur } & \multicolumn{3}{l}{ Tidak Teratur } \\
\cline { 2 - 6 } Berat Badan & Pre & Post & \multicolumn{1}{l}{ Pre } & Post \\
& Test & Test & Test & Test \\
& $\mathbf{( k g )}$ & $\mathbf{( k g )}$ & $\mathbf{( k g )}$ & $\mathbf{( k g )}$ \\
\hline Rerata & 14,80 & 15,16 & 14,56 & 14,52 \\
SD & 1,63 & 1,74 & 1,26 & 1,14 \\
Minimum & 12,43 & 13,08 & 12,72 & 12,90 \\
Maximum & 18,38 & 19,32 & 17,93 & 16,67 \\
Nilai p & \multicolumn{2}{c}{0,051} & \multicolumn{3}{c}{0,682} \\
\hline
\end{tabular}

Berdasarkan analisis uji $t$ berpasangan pada kedua kelompok penelitian dengan derajat kepercayaan 95\% didapatkan perbedaan yang bermakna pada BB dan TB serta pada IMT didapatkan hasil yang tidak bermakna. Berdasarkan Uji Anova one way antar kelompok perlakukan dengan derajat kepercayaan 95\% didapatkan nilai yang tidak bermakna pada BB, TB dan IMT.

\section{PEMBAHASAN}

Penilaian status BB, TB menunjukan adanya perbedaan yang bermakna BB sebelum dan sesudah perlakuan pada kedua kelompok. Hasil uji $t$ berpasangan terhadap pengukuran rerata $\mathrm{BB}$, TB pre test dan post test untuk kelompok teratur mengkonsumsi suplemen zink dengan kelompok yang tidak teratur mengkonsumsi suplemen zink masingmasing $p=0,000, p=0,000, p=0,000, p=0,000$. Hal ini sesuai dengan penelitian metaanalisis yang menggunakan beberapa data tentang pengaruh zink terhadap berat badan, tinggi badan dan dilakukan perbandingan antar penelitian tersebut. Penelitian tersebut menyimpulkan bahwa pemberian suplemen zink berdampak signifikan terhadap peningkatan berat badan dan tinggi badan. ${ }^{15}$ Penelitian lain yang dilakukan pada anak sekolah dasar dengan memberikan suplemen zink menyimpulkan suplementasi zink terhadap berat badan dan tinggi badan sudah berpengaruh dalam satu bulan pemberian. $^{21}$

Peningkatan BB,TB pada kedua kelompok terutama pada kelompok teratur sebagai akibat dari peningkatan nafsu makan, penurunan angka kejadian infeksi dan peningkatan IGF-I. Terjadinya peningkatan nafsu makan akan meningkatan jumlah asupan kalori dan protein anak sehingga dengan konsumsi yang teratur intake akan meningkat dibanding yang tidak teratur. Kalori yang berlebih akan disimpan dalam bentuk jaringan lemak dan protein berfungsi untuk meningkatkan massa otot serta mineral sebagai enzim untuk pertumuhan. ${ }^{22,23}$ Pemberian suplemen zink juga menurunkan insidensi terjadinya diare, pneumonia dan penyakit infeksi lainnya. Penyakit infeksi tersebut nantinya akan menurunkan berat badan penderitanya. ${ }^{15}$ Zink menginduksi neuropeptida pada hipotalamus, sekresi $\mathrm{GH}$, sensitivitas $\mathrm{GH}$ endogen, bioaktvitas $\mathrm{GH}$ dan Reseptor $\mathrm{GH}$. Zink merangsang $\mathrm{GHRH}$ yang nantinya akan merangsang area somatrotropik pituitary yang mensekresikan $\mathrm{GH}$. Zink 
bertanggung jawab pada perumbuhan tulang longitudinal terutama pada sel kondrosit di epifisis. Jadi zink berpengaruh pada semua mekanisme pertumbuhan sel dan tulang. ${ }^{23}$

Penilaian status IMT menunjukan tidak ada perbedaan yang bermakna IMT sebelum dan sesudah perlakuan pada kedua kelompok. Hasil uji $t$ berpasangan terhadap pengukuran rerata IMT pre test dan post test untuk kelompok teratur mengkonsumsi suplemen zink dengan kelompok yang tidak teratur mengkonsumsi suplemen zink masing-masing $p=0,051$ dan $p=0,682$. Hal ini tidak sesuai dengan penelitian yang di lakukan pada pasien anak yang mengalami cystic fibrosis yang menyimpulkan bahwa pemberian suplemen zink berdampak signifikan terhadap peningkatan IMT. ${ }^{24}$ Penelitian ini dilakukan selama tiga bulan tanpa memperhatikan faktor penyakit lain.

Pengukuran BB, TB dan IMT menunjukan hasil yang tidak bermakna antara kelompok yang mengkonsumsi suplemen zink secara teratur dengan kelompok yang mengkonsumsi suplemen zink secara tidak teratur. Hasil uji Anova one way terhadap pengukuran BB, TB dan IMT post test diantara kedua kelompok didapatkan $p=0,053 p=0,117$ dan $p=0,211$. $\mathrm{Hal}$ ini terbukti oleh penelitian metaanalisis yang dilakukan pada anak dengan usia 1-8 tahun dengan membandingkan tinggi badan antara kelompok yang diberi zink dengan kelompok kontrol menunjukan nilai yang tidak bermakna pada 6 bulan suplementasi zink, sedangkan pada penelitian ini membandingkan pola konsumsi zink teratur dengan tidak teratur dalam waktu 3 bulan. ${ }^{25}$

\section{SIMPULAN}

Ada pengaruh pemberian suplemen zink terhadap BB, TB, dan IMT anak SDN 13 Batang Anai.

\section{DAFTAR PUSTAKA}

1. Stalker P, Syebubakar A, Hadar I, Ega L, Parray O, Hutahayan R, Ady SK. Millennium development goals. Edisi ke-2. Jakarta: BAPPENAS; 2008.

2. Kementerian Kesehatan RI (Kemenkes RI). Rencana strategis kementrian kesehatan tahun 2015-2019. Jakarta: Kemenkes RI; 2015.
3. Direktorat Gizi Masyarakat. Pedoman perbaikan gizi anak sekolah dasar dan madrasah ibtidaiyah. Jakarta: Departemen Kesehatan Rl; 2005.

4. Morales MSV, Rubio NL, Ruso C, Llopis AG, Ruiz ER, Rendondo $\mathrm{M}$, et al. Anthropometric status and nutritional intake in children (6-9 years) in Valencia (Spain): the aniva study. Int $\mathrm{J}$ Environ Res Public Health. 2015;(12):16082-95.

5. Saputra, Nurrizka RH. Faktor demografi dan risiko gizi buruk dan gizi kurang. Makara. 2012; 16(2) 95101.

6. Pahlevi AE. Determinan status gizi pada siswa sekolah dasar. Kemas. 2012;7(2):122-6.

7. World Health Organization (WHO). Prevalence of thinness among children and adolescents, BMI < 2 standard deviation below the median, crude estimates by WHO region. (diunduh Januari 2018). Tersedia dari: http://apps.who.int/gho/data/ view.main.NCDBMIMINUS2CREGv?lang=en

8. Badan Penelitian dan Pengembangan Kesehatan. Riset kesehatan dasar (Riskesdas) 2013. Jakarta: Kementrian Kesehatan RI; 2013.

9. Handayani LR, Lestari D, Aimanah IU, Ipa M, Herman S, Suprapto A. Riskesdas dalam angka Provinsi Sumatera Barat tahun 2013. Jakarta: Kemenkes RI; 2013.

10. Rosmalina Y, Ernawati F. Hubungan status zat gizi mikro dengan status gizi pada anak remaja SLTP. PGM. 2010; 33(1):14-22.

11. Herman S. Review on the problem of zinc defficiency, program prevention and its prospect. Media Penelit dan Pengembang Kesehat. 2009; 19(2):75-83.

12. Prasad AS. Discovery of human zinc deficiency: its impact on human health and disease. Adv Nutr. 2013;4:176-90.

13. Liberato SC, Singh G, Mulholland K. Zinc supplementation in young children: a review of the literature focusing on diarrhoea prevention and treatment. Clin Nutr. 2014;34(2):1-8.

14. Widhyari SD. Peran dan dampak defisiensi zinc (Zn). Wartazoa. 2012; 22(3):141-8.

15. Brown KH, Peerson JM, Baker SK, Hess SY. Preventive zinc supplementation among infants, preschoolers, and older prepubertal children. Food and Nutrition Bulletin. 2009;30(1):12-40. 
16. Sandstead HH. Zinc deficiency a public health problem. Am J Dis Child. 1991;145(8):853-9.

17. Fahmida $U$, Rumawas JW, Utomo B, Patmonodewo S, Schultink W. Zinc-iron, but not zinc-alone supplementation, increased linear growth of stunted infants with low haemoglobin. Asia Pac J Clin Nutr. 2007;16(2):301-9.

18. Kusudaryati DPD. Kekurangan asupan besi dan seng sebagai faktor penyebab stunting pada anak. Profesi. 2014;10:57-62.

19. Locks LM, Manji KP, McDonald CM, Kupka R, Kisenge $\mathrm{R}$, Aboud $\mathrm{S}$, et al. Effect of zinc and multivitamin supplementation on the growth of Tanzanian children aged 6-84 wk: a randomized, placebo-controlled,double-blind trial. Am J Clin Nutr. 2016;103:910-8.

20. Stephenson TJ, Schiff WJ. Human nutrition science for healty living. New York: McGraw-Hill Education; 2016.

21.Shofiya D. Pengaruh suplemetasi zn (seng) terhadap status gizi anak sekolah dasar di Kecamatan Sedati Kabupaten Sidoarjo Jawa
Timur.(tesis). Surabaya. ADLN-Perpustakaan Universitas Airlangga; 2004.

22. Chao HC, Chang YJ, Huang WL. Cut-off serum zinc concentration affecting the appetite. Nutrition in Clinical Practice. 2018;00(0):1-10.

23.Rocha EDdM, Brito NJNd, Dantas MMG, Silva AdA, Almeida MdG, Neto JB. Effect of zinc supplementation on GH, IGF1, IGFBP3,OCN, and ALP in non-zinc-deficient children. Journal of the American College of Nutrition. 2015:290-9.

24. Ataee $P$, Najafi M, Gharagozlou M, Aflatounian M, Mahmoudi M, Khodadad A, et al. Effect of supplementary zinc on body mass index, pulmonary function and hospitalization in children with cystic fibrosis.The Turkish Journal of Pediatrics. 2014; 56:127-32.

25.Stammer AL, Lowe NM, Medina MW, Patel S, Dykes F, Rodrigo CP, et al. The relationship between zinc intake and growth in children aged 18 years: a systematic review and meta-analysis. European Journal of Clinical Nutrition. 2015; 69: 147-53. 